\title{
Unique landscape of widespread chromosomal losses in Hürthle cell carcinoma
}

In their back-to-back published articles 'Integrated Genomic Analysis of Hürthle Cell Cancer Reveals Oncogenic Drivers, Recurrent Mitochondrial Mutations, and Unique Chromosomal Landscapes' and 'Widespread Chromosomal Losses and Mitochondrial DNA Alterations as Genetic Drivers in Hürthle Cell Carcinoma' Ganly et al. (2018) and Gopal et al. (2018), respectively, defined alterations in oncogenic drivers and mitochondrial DNA mutations complex I (mtDNA), including the widespread whole-chromosome losses in oncocytic or Hürthle cell thyroid carcinoma (HCC). This comprehensive analysis further unravels the unique features of HCC, either minimal or widely invasive in character and confirms previous work published on mtDNA mutations as well as the widespread loss of entire chromosomes (Bonora et al. 2006, Gasparre et al. 2007, Corver et al. 2012, 2014).

In this letter, we want to address the questions left unanswered in both manuscripts. A possible mechanism behind the observed whole-chromosome losses as well as the possible occurrence of such chromosomal losses in benign Hürthle cell lesions (adenomas) was not discussed or studied. Thirdly, Ganly et al. (2018) and Gopal et al. (2018) both use the term uniparental disomy of which the use, to our opinion, should be restricted to single chromosomal events rather than the widespread loss of many entire chromosomes as observed in HCC. Finally, a significant number of the HCCs studied in these papers do not show mtDNA mutations, confirming our earlier finding (Corver et al. 2014) and pointing to another origin of the mitochondrial expansion and the widespread loss of entire chromosomes so typically for oncocytic lesions.

We described a range of whole-chromosome copy number changes observed in Hürthle cell adenomas (HCA) (Corver et al. 2017). The occurrence of genetic alterations in Hürthle cell hyperplasia and HCA was also studied by Nikiforova et al. in their evaluation of the ThyroSeq v3 genomic classifier for preoperative cytological analysis of thyroid nodules (Nikiforova et al. 2018). Chromosomal copy number alterations were observed in 33\% of the
Hürthle cell adenomas but not in Hürthle cell hyperplasia. No specific chromosomal information was given. From our observations, we developed a model for HCC (annotated at the time as FTC-OV by us) based on wholechromosome instability (w-CIN) and step-wise loss of whole chromosomes during tumor progression, thereby leading to near-homozygous genomes (NHGs). We found support that excessive amounts of reactive oxygen species (ROS) likely initiate the process (Corver et al. 2017).

One of characteristics of HCC is the abundance of dysfunctional mitochondria producing elevated levels of ROS. Without significant DNA damage, ROS can activate the ATM-CHK2 pathway (Alexander et al. 2010, Guo et al. 2010). Simultaneously, ATM-CHK2 activation causes increased kinetochore-microtubule stability during mitosis causing lagging chromosomes (Bakhoum et al. 2014). We studied the number of chromosome missegregations in cell line models for thyroid cancer with and without NHG. Amongst these were XTC.UC1 cells, the only official model for HCC and FTC-236 cells, both showing a NHG highly comparable to the NHGs found in clinical HCC, including retention of chromosome 7. FTC-236 cells (including FTC-133 and FTC-238, derived from different metastasis from the same patient) were previously reported to originate from a follicular thyroid cancer and not from HCC (Demeure et al. 1992). Chromosome missegregations were substantially higher in XTC.UC1 and in FTC-236 than the other thyroid cancer cell lines that did not show a NHG and were significantly reduced after ROS scavenger experiments. From FTC-236 cells we were able to isolate subclones all showing a unique pattern of a NHG pointing to continuing w-CIN in this cell line model. One minimal-invasive HCC showed wholechromosome imbalances, which can be attributed to intratumor heterogeneity caused by an admixture of populations: one heterozygous (two copies) and one homozygous (one copy) for the involved chromosomes. Strikingly, the affected chromosomes $(1,2,8,9,18$ and 22) present in variant frequencies in HCA samples showed to be homozygous in all HCCs analyzed, suggesting selection for the loss of these Printed in Great Britain 
chromosomes during clonal outgrowth. Furthermore, from one case we obtained two samples from the primary tumor that clearly displayed different NHGs, again demonstrating $\mathrm{w}$-CIN leading to intra-tumor heterogeneity.

In the context of the proposed progression model of HCC, flow cytometric DNA content analysis of HCA and HCC revealed that a near-haploid state precedes the endoreduplicated and aneuploid state caused by genome doubling (Corver et al. 2017). Genome doubling is a common feature of carcinomas. For example, studies on DNA content analysis clearly revealed a bi-model distribution of the DNA content of many carcinomas in which a step of tetraploidization (endoreduplication of a DNA diploid population) precedes aneuploidization, for example, in Barrett's esophagus and breast cancer (Devilee \& Cornelisse 1994, Galipeau et al. 1996). Thus, the copy neutral LOH of many entire chromosomes found in HCC is the consequence of genome doubling after a process of near-haploidization rather than uniparental disomy, as proposed by Ganly et al. and Gopal et al., which involves two copies of a chromosome as the consequence of a meiosis I or II error (Robinson 2000). The proposed mechanism seems to operate in other types of cancers showing oncocytic subtypes with a NHG, like adrenal cortical cancer, isolated parathyroid cancers (Corver et al. 2014), acute lymphoblastic leukemia (Holmfeldt et al. 2013) and a subset of chondrosarcoma (Bovee et al. 2000).
Whole chromosome genomic alterations can also have unexplained features in thyroid cancer. We found exceptional cases of non-oncocytic follicular thyroid cancers with widespread whole chromosome gains that cannot be explained by genome endoreduplication and additional alterations of whole chromosomes. Figure 1 is a clear example of DNA aneuploid FTC with a DNA index of 1.26 with widespread whole-chromosome copy number changes, foremost with whole chromosomal gains and only one (chromosome 3) showing copy-neutral LOH.

Better understanding of the molecular mechanisms underlying the widespread w-CIN might lead to new therapeutic options highly needed for these types of aggressive cancers. Furthermore, it would be interesting to study the exact role of mtDNA mutations in HCC. Also by Ganly et al. and Gopal et al., it was proposed that complex I mtDNA mutation plays a pivotal role in the development and progression of HCC (Gasparre et al. 2007). Conversely, we and Ganly et al. and Gopal et al. also showed that many remaining HCCs with NHG do not carry disruptive (or damaging) complex I mtDNA mutations. Apparently, alternative explanations should be found. One avenue that might be further explored is the hypothesis that extensive mitochondrial hyperplasia found in HCC is driven by a mitochondrial coupling defect (Savagner et al. 2001). The latter might give clues for alternative explanations for the observed NHG.
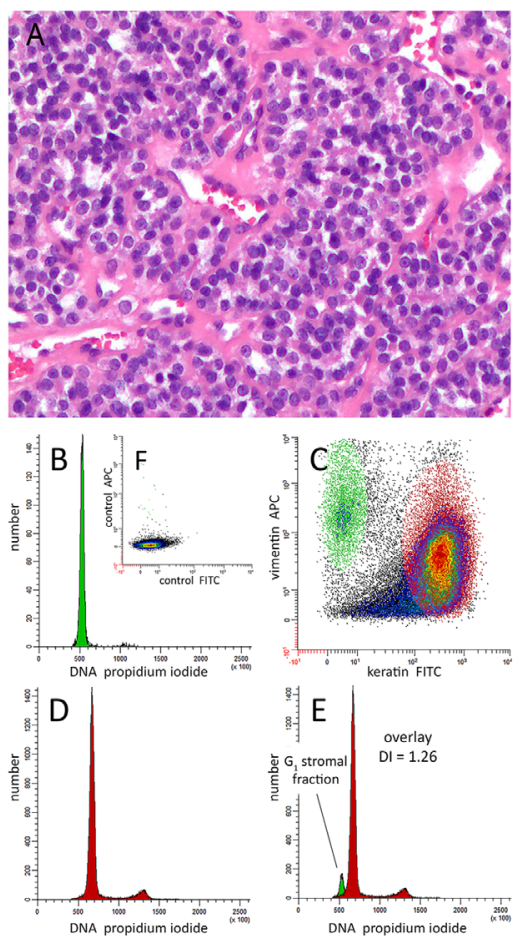

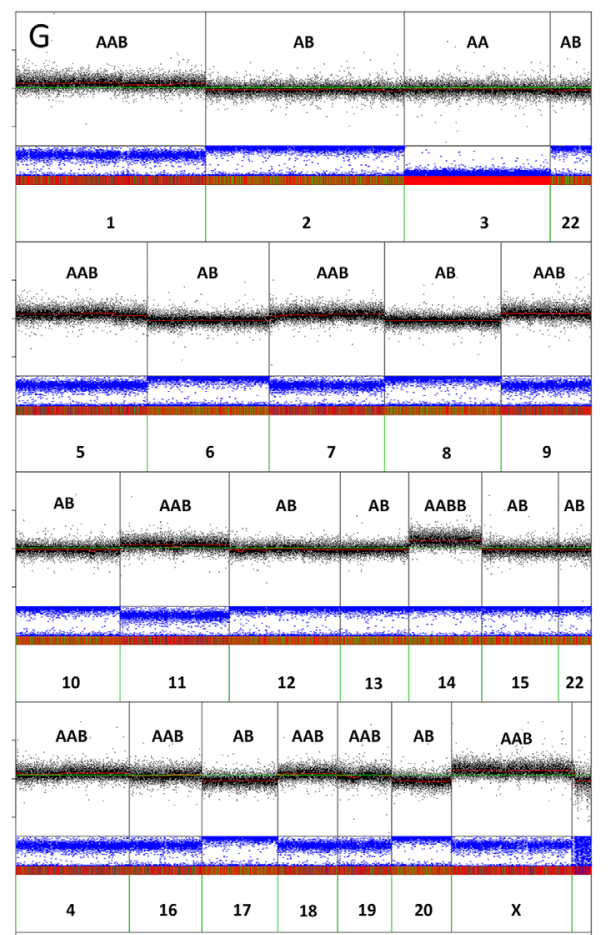

Figure 1

A DNA aneuploid follicular thyroid carcinoma (FTC) with widespread whole-chromosome copy number changes. (A) H\&E section (40x) from a formalinfixed, paraffin-embedded specimen of the thyroid tumor. Punches from the same tissue block were used for preparing a cell suspension which was labeled for keratin (FITC), vimentin (APC) and DNA (PI) and analyzed on an LSRII (BD Biosciences) flow cytometer (Corver et al. 2005). (B) DNA histogram of the vimentin-positive stromal fraction (green, internal reference), (C) keratin vs vimentin dot plot. Note that most of the carcinoma cells show vimentin co-expression, (D) DNA histogram of the keratin-positive carcinoma fraction (red), (E) overlay DNA histograms stromal fraction and carcinoma fraction. The DNA index (DI) was 1.26 (ModFit analysis, Verity Software House). (F) (inlay) negative control showing green and deep red background fluorescence. (G) DNA was extracted from a corresponding frozen section of the same FTC and prepared for single nucleotide polymorphism analysis (cytoSNP, Illumina). Note that chromosome 3 shows copy-neutral LOH (AA). Chromosomes 2, 6, $8,10,12,13,15,17$ and 20 are heterozygous with two copies (AB). Chromosome 14 shows four copies (AABB). The other chromosomes are imbalanced with three copies (AAB). 
Willem E Corver

Hans Morreau

\section{Department of Pathology, Leiden University Medical \\ Center, Leiden, The Netherlands}

(Correspondence should be addressed to W E Corver and H Morreau: w.e.corver@lumc.nl and j.morreau@lumc.nl)

\section{Declaration of interest}

The authors declare that there is no conflict of interest that could be perceived as prejudicing the impartiality of this article.

\section{Funding}

This work did not receive any specific grant from any funding agency in the public, commercial or not-for-profit sector.

\section{Author contribution statement}

W E C and $\mathrm{H} M$ wrote the manuscript.

\section{References}

Alexander A, Cai SL, Kim J, Nanez A, Sahin M, MacLean KH, Inoki K, Guan KL, Shen J, Person MD, et al. 2010 ATM signals to TSC2 in the cytoplasm to regulate mTORC1 in response to ROS. PNAS $\mathbf{1 0 7}$ 4153-4158. (https://doi.org/10.1073/pnas.0913860107)

Bakhoum SF, Kabeche L, Murnane JP, Zaki BI \& Compton DA 2014 DNA-damage response during mitosis induces whole-chromosome missegregation. Cancer Discovery 4 1281-1289. (https://doi. org/10.1158/2159-8290.CD-14-0403)

Bonora E, Porcelli AM, Gasparre G, Biondi A, Ghelli A, Carelli V, Baracca A, Tallini G, Martinuzzi A, Lenaz G, et al. 2006 Defective oxidative phosphorylation in thyroid oncocytic carcinoma is associated with pathogenic mitochondrial DNA mutations affecting complexes I and III. Cancer Research 66 6087-6096. (https://doi. org/10.1158/0008-5472.CAN-06-0171)

Bovee JV, van Royen M, Bardoel AF, Rosenberg C, Cornelisse CJ, CletonJansen AM \& Hogendoorn PC 2000 Near-haploidy and subsequent polyploidization characterize the progression of peripheral chondrosarcoma. American Journal of Pathology 157 1587-1595 (https://doi.org/10.1016/S0002-9440(10)64796-7)

Corver WE, Ter Haar NT, Dreef EJ, Miranda NF, Prins FA, Jordanova ES, Cornelisse CJ \& Fleuren GJ 2005 High-resolution multi-parameter DNA flow cytometry enables detection of tumour and stromal cell subpopulations in paraffin-embedded tissues. Journal of Pathology 206 233-241.(https://doi.org/10.1002/path.1765)

Corver WE, Ruano D, Weijers K, den Hartog WC, van Nieuwenhuizen MP, de Miranda N, van Eijk R, Middeldorp A, Jordanova ES, Oosting J, et al. 2012 Genome haploidisation with chromosome 7 retention in oncocytic follicular thyroid carcinoma. PLOS ONE 7 e38287. (https://doi.org/10.1371/journal.pone.0038287)

Corver WE, van WT, Molenaar K, Schrumpf M, van den Akker B, van ER, Ruano ND, Oosting J \& Morreau H 2014 Near-haploidization significantly associates with oncocytic adrenocortical, thyroid, and parathyroid tumors but not with mitochondrial DNA mutations. Genes, Chromosomes and Cancer 53 833-844. (https://doi. org/10.1002/gcc.22194)

Corver W, Demmers J, Oosting J, Sahraeian S, Boot A, Ruano D, van Wezel T \& Morreau H 2017 ROS-induced near-homozygous genomes in thyroid cancer. Endocrine-Related Cancer 25 83-97. (https://doi. org/10.1530/ERC-17-0288)

Demeure MJ, Damsky CH, Elfman F, Goretzki PE, Wong MG \& Clark OH 1992 Invasion by cultured human follicular thyroid cancer correlates with increased beta 1 integrins and production of proteases. World Journal of Surgery 16 770-776. (https://doi.org/10.1007/BF02067383)

Devilee P \& Cornelisse CJ 1994 Somatic genetic changes in human breast cancer. Biochimica et Biophysica Acta 1198 113-130. (https:// doi.org/10.1016/0304-419X(94)90009-4

Galipeau PC, Cowan DS, Sanchez CA, Barrett MT, Emond MJ, Levine DS, Rabinovitch PS \& Reid BJ 1996 17p (p53) allelic losses, 4N (G2/ tetraploid) populations, and progression to aneuploidy in Barrett's esophagus. PNAS 93 7081-7084. (https://doi.org/10.1073/ pnas.93.14.7081)

Ganly I, Makarov V, Deraje S, Dong Y, Reznik E, Seshan V, Nanjangud G, Eng S, Bose P, Kuo F, et al. 2018 Integrated genomic analysis of Hurthle cell cancer reveals oncogenic drivers, recurrent mitochondrial mutations, and unique chromosomal landscapes. Cancer Cell 34256. e255-270.e255. (https://doi.org/10.1016/j.ccell.2018.07.002)

Gasparre G, Porcelli AM, Bonora E, Pennisi LF, Toller M, Iommarini L, Ghelli A, Moretti M, Betts CM, Martinelli GN, et al. 2007 Disruptive mitochondrial DNA mutations in complex I subunits are markers of oncocytic phenotype in thyroid tumors. PNAS 104 9001-9006. (https://doi.org/10.1073/pnas.0703056104)

Gopal RK, Kubler K, Calvo SE, Polak P, Livitz D, Rosebrock D, Sadow PM, Campbell B, Donovan SE, Amin S, et al. 2018 Widespread chromosomal losses and mitochondrial DNA alterations as genetic drivers in Hurthle cell carcinoma. Cancer Cell 34 242.e245-255.e245. (https://doi.org/10.1016/j.ccell.2018.06.013)

Guo Z, Kozlov S, Lavin MF, Person MD \& Paull TT 2010 ATM activation by oxidative stress. Science 330 517-521. (https://doi.org/10.1126/ science.1192912)

Holmfeldt L, Wei L, Diaz-Flores E, Walsh M, Zhang J, Ding L, PayneTurner D, Churchman M, Andersson A, Chen SC, et al. 2013 The genomic landscape of hypodiploid acute lymphoblastic leukemia. Nature Genetics 45 242-252. (https://doi.org/10.1038/ng.2532)

Nikiforova MN, Mercurio S, Wald AI, Barbi de Moura M, Callenberg K, Santana-Santos L, Gooding WE, Yip L, Ferris RL \& Nikiforov YE 2018 Analytical performance of the ThyroSeq v3 genomic classifier for cancer diagnosis in thyroid nodules. Cancer 124 1682-1690. (https:// doi.org/10.1002/cncr.31245)

Robinson WP 2000 Mechanisms leading to uniparental disomy and their clinical consequences. BioEssays 22 452-459. (https://doi.org/10.1002/ (SICI) 1521-1878(200005)22:5<452::AID-BIES7>3.0.CO;2-K)

Savagner F, Franc B, Guyetant S, Rodien P, Reynier P \& Malthiery Y 2001 Defective mitochondrial ATP synthesis in oxyphilic thyroid tumors. Journal of Clinical Endocrinology and Metabolism 86 4920-4925. (https://doi.org/10.1210/jcem.86.10.7894)

Received in final form 6 December 2018

Accepted 21 December 2018

Accepted Preprint published online 21 December 2018 https://erc bioscientifica.com https://doi.org/10.1530/ERC-18-0481
C 2019 Society for Endocrinology Published by Bioscientifica Ltd. Printed in Great Britain 